\title{
Representation of the Rohingyas in Media and New Media: Narrative, Analysis, and Re-thinking
}

\author{
Abdur Rahim, Sadat Zaman Khan \\ Assistant Professor, Department of English Language and Literature (DELL), Premier University, Chittagong, Bangladesh
}

\begin{abstract}
Among the recent most-talked issues in the international arena, the Rohingya issue in Myanmar draws the attention of the critical circles. Representation of them in the media and new media covers a vast critical space because of their complex position in the country as Muslims and minority. Moreover, their anthropological and religious resemblance with the people of the neighbouring country Bangladesh has more complicated the issue. The world is divided into two poles regarding Myanmar's claim of the Rohingyas' non-nationality and Bengali identity. The topic is relentlessly discussed in both media and new media. The representation is mixed in the media because of different political interests while it is almost one dimensional in the new media. This paper, first of all, shows the way of the representation of the Rohingyas in the media and the new media regarding their exodus to the neighbouring country Bangladesh, and their lives as refugees. Secondly, it highlights how the conventional media fail to bring out the realities about an ethnic group suppressed in multifaceted ways and thirdly, it analyses the role of the new media where discourses appear relentlessly from different sources irrespective of religions, cultures, boundaries, and ideologies.
\end{abstract}

Keywords: media, new media, refugee, Rohingya, representation, migration

\section{INTRODUCTION}

\section{Media, New Media, and Conventional Power Paradigm}

$\mathrm{T}$ he world is now under some super powers which control the global politics, economy, culture, and ideology. For referring to the absolute power of the powerful nations, Robert Corfe exemplifies America and her policies by adding that "America is not a place where reason is allowed to reign. Only the rude bully is allowed to sway on issues which really matter" (131). From state politics to production to enactment of law, everything is designed in this country with a view to materializing her ideology. Almost all the capitalist countries possess the similar types of tendencies. Apart from the political absolutists, there are some other institutions such as media which propagandize and to some extent, control the views of the nations about the target groups. Media has become the "fourth estate" (Allan, 3) as coined by Edmund Burke which is attributed with social, political, cultural, economic, corporate, religious, and ideological dichotomies of the regular estate. They behave like a state with all of its realities. Their policy of representing a nation is determined by the factors introduced and practiced by the oppressive super-powers. There has been a canonical tendency in the publication policies of the media which are mostly aligned with the central state policies. It becomes more aggressive in those countries with absolute rule in which democracy is not practised. The universal objective of publishing print media is denied in these countries. What is projected by Danis McQuail about it is that print media "is governed by guarantees of freedom of expression" (22). Censorship is extremely prohibited in the field of media. Some countries such as Myanmar impose censorship on the media in representing the indigenous people like the Rohingyas. Bhatia, Poynting, and Tofail comment that in Myanmar, the media cannot represent the Rohingyas because of the government's "... direct censorship and repression on the media" (169) and for this, "there is virtually no independent media coverage of events in Rakhaine State" (169). Thus, the Rohingyas are not truly represented in the state media because of extreme stateintervention.

The whole world is divided into two parts regarding the Rohingya crisis. Some of the countries are directly involved in pressurizing Myanmar for solving it while others work for finding out an acceptable way out to this formidable situation. It is to be noted here that the roles of media in different countries get changed with the governments' political decisions. It goes without question that money determines the functional policies of a company and in this line of thought, Chinenye (2012) shows how advertisement confirms the survival of a media organization (308-322). Without having enormous governmental support, it is quite impossible for them to survive in the competitive market. For this reason, most of them go with compromising tendencies with the power-poles. Contrarily, with the emergence of the new media, the corporate isms of the monarchial media Mughals are shattered as they provide alternative broadcasting systems. In this system, the control of the government is less and corporate control does not function properly. The individuals can participate in new media freely. What is very remarkable regarding the new media is that the participants can share their views against any atrocities happened anywhere in the world. It creates a borderless globe in which all individuals put comments for or against any happening. Thus, it can represent the afflicted groups or individuals enormously which is very much absent in the conventional media.

\subsection{Terminologies}

In this writing, I have classified media mainly into two parts such as conventional print and electronic media and the new media. The term conventional media has different meanings in different centuries. In the $18^{\text {th }}$ century, it referred to the mass 
media such as newspaper and in the $19^{\text {th }}$ century, "electricity was a medium" (Chun 3). Later, with the introduction of the televised media, the term refers to an extended version of media including print media and electronic media. New media indicates the social sites including Facebook, Twitter, Messenger, Youtube, Instagram etc.

\section{METHODOLOGY}

The article is developed following the qualitative method. As the Facebook is a widely known phenomenon in the present world, the documents in the forms of status and comments given on it and news feeds available in different print and electronic media are studied elaborately with a view to critically analysing the roles played by both media and new media in representing the Rohingya refugees.

\section{Role of Conventional Media and their Limitations:}

David Croteau and William Hoyness, in their The Business of Media: Corporate Media and the Public Interest, have brought out the functions of the media by stating that “... the media deal in ideas, information, and culture. They inform and entertain us, influencing how we understand ourselves and our world, ...they play significant political and cultural roles,... hold independent thought and diverse perspectives" (01). In the field of media studies, the canonical literary aspects can easily be incorporated with a view to concentrating on the roles of media where the historically, ethically, and universally accepted issues are placed with great importance. Moreover, the issue namely representation in media is a vital perspective as the present world is a complex paradigm constantly guided by different social, political, economic, cultural, ideological, and technological paradigms. The idea of representation in the communication science is usually considered a paradigm full of "nuances and complexity" (Fourie, 198) because of its multidimensional definitions. Fourie, in his Media Studies: Media History, Meida and Society, defines representation from two perspectives which include the simple act of representation and the perception developed for this act and representation as the "making of the sign" (198) which is a theoretical discourse. He furthers the idea by stating that representation refers to the production of the real object in the realities of media which aims to attribute meaning to the newly produced phenomenon. The whole process is a scrutinized version which has to compromise with many realties and the process becomes an imbalanced dichotomy of the reality and the representation. Fourie furthers the idea by adding-

In media studies we accept the assumption that all representations are simply mediations: mediated versions of reality. A television news program, for example, does not and can never offer the whole of the reality of the reported event. Only one superficial and restricted view of events is possible. The event is inevitably mediated and a quality of fakeness and artificiality is in some ways therefore an integral part

\author{
of televised (or any other type of media) is \\ representation. (200)
}

The understanding of the limitation of the media takes us to some more of its drawbacks which are lack of authenticity, reliability, and truth and all of these are very detrimental for the media resources. But the target end point of this discussion is to show how media representation stumbles because of its wide involvement with different institutions and how this affiliation keeps them away from representing a suppressed nation, voicing them properly to reach their goal and achieve their desired freedom.

\section{ROHINGYAS AND THEIR REPRESENTATION IN THE MEDIA: NARRATIVE AND LIMITATIONS}

The suppression of the Rohingyas in Myanmar is a very widely-discussed issue in the national and international media as the state-controlled army of Myanmar has been deployed to uproot them and compel them to migrate to the neighbouring country Bangladesh. It attracts the attention of the international community as different international agencies have condemned Myanmar for ethnic cleansing in the Rohingya-populated area. Innumerable narratives have been produced for and against the Rohingyas reflecting the political and religious polarisation of the governments of different countries. The roles of the media in determining the interests of the news about the Rohingyas are also guided by the political or corporate paradigms of their own countries. Thus, the narratives on the Rohingya refugees occupy very complex spaces in the critical arena.

Religious Historiography of the Rohingyas and the Representation of them in the Media

There has always been a tendency to create a borderless and one-cultural state throughout the world which is proved to be a failure because of the realization that the world will exist with all of the social, cultural, political, ideological, and economic disparities among the nations and races. This one dimensionality in the understanding of the human race can be paralleled to the theoretical paradigm entitled structuralism which offers a universal structure of understanding a system. Fardinand de Saussure, a Swiss linguist, in his The Course in General Linguistics, tries to offer a universal linguistic pattern for understanding all the languages of the world. He, perceiving all the disparities among the languages, comes to a universal understanding of all the languages by concentrating on the fact that "it is therefore possible to conceive of a science which studies the role of signs as part of social life" (Lodge 8). Through this semiology or the study of sings, he attempts to understand the languages homogenously and thus, he universalizes the structures of all the languages. This idea is used to understand the nature of the conventional media of the world. The mono-system project to understand humanity as proposed by structuralism has failed in the post-war world while multiculturalism and pluralism are welcomed in the postcolonial era. The world has also gone through a new dimension in the world with the experience of $1 / 11$ alma 
mater where religion has become the deciding factor regarding humanity. Some people with particular religious identity, particularly the Muslims, have been subalternised and attributed with static and rigid ideologies that these people are endless suppliers of terrorism and atrocities through out the whole world. England, the land of liberal thoughts and enlightenment, has gone for Brexit, with a view to promoting some of the ideas of her super-power comrade America which is perceived by T. J. Coles, in his The Great Brexit Swindle: Why the Mega Rich and Free Market Fanatics Conspired to Force Britain from the European Union, as a support to "America's financial and geopolitical interest" (03). In this quotation, the American geopolitical interest is the keywords which are very important for understanding the canonical media's reluctance to the Rohingyas of Myanmar. After 1/11, the Americans possess very strong belief that the Muslims are the exporters of world-wide terrorism. Moreover, the recent American election also reflects the central notion of the Americans who have elected a person with heinous ideology of abolishing the Muslims from the country. The selection of Trump as their president is the proof of their one dimensionality regarding nationhood and race. Their common perception against the Muslims is brought out by Green. According to him, "politics and policies frame Muslims as terrorist suspects and national security threats, under the assumption Islam itself is inherently violent and Muslims by default are guilty of terrorist tendencies. That's why, Muslims must be managed, registered, and surveilled, or worse". (27)

Their belief has been transmitted to the media which are canonical and considered international movers through their reports and propagandas. As the Western countries are antiMuslims in most of the cases, the crisis concerning the Muslims fails to appeal them at all. For this reason, the Rohingya crisis has not been highlighted in the Western electronic and printing media as it is required. Even they have not put due emphasis on the refugee problem Bangladesh is facing because of the Rohingyas in her border areas. The Western media agencies behave like neo-imperial agents concerning the Rohingya Muslims and these outlooks have been very much spontaneous, fixed, and unalterable to them .

\section{Populism and the Silence of the Media}

The recent world has also experienced the revival of extreme nationalism in the developed world which once was practiced and promoted with the notions of multiculturalism and liberalism. The occidental countries are now going after the consents of the commoners which is reflected in the choices of their ideological patterns and leaderships. More particularly, Brexit in England and Trump in America are the ready-made examples of the extreme nationalism of these nations commonly known as populism. The most remarkable aspect of this ism is the inevitable disbelief and sense of separation with other races. Francisco Pinazza, in his Populism and the Mirror of Democracy, concentrates on the theme of the divisionality promoted by the term by saying that it refers to the "dichotomization of the social space through the creation of an internal frontier, and the construction of an equivalential chain between unfulfilled demands" (38). This historical transition of the Westerners is to be understood through the ruptures they assume they have because of the other races particularly by the Muslims. This is a political game and Western media can't ignore this paradigm as they also possess the same view regarding knowledge what Edward Said suggests in his Orientalism by saying that no knowledge is apolitical. According to him, any idea produced in the social, cultural, ideological, literary, religious, or philological structures must have a political connection. To him, this kind of knowledge is not "... therefore automatically nonpolitical" (10). The non-Muslim world is silent about the army oppression in Myanmar on the Rohingyas because of the populist ideas. My argument is that the media of these countries is not also out of this fixity of ideologies, rather they move with the current. For this reason, they are not very critical to the rape of the Rohingya women by the army, burning of their houses, and forced migration to Bangladesh.

\section{Structural Structure of the Conventional Media and the Representation of the Rohingyas}

The analysis of the traditional and colonial mentality of the media of the non-Muslim world is taken as one of the core ideas in this essay. Throughout the ages, there has been a binary namely west/east or occident/orient, a project as coined by Said designed by the Westerners with a view to subordinating and undermining the easterners as others in the colonial discourse. The politicized, ideologised, and propagandised ideas of the state have been soundly transmitted to the countries' media and they have never come out of these imperial attitudes. These conventional media ideologies are visible in their representation of the Rohingya refugees. Ferdinand de Saussure's structural linguistic model can be applied here with a view to proving the dichotomized representation of the Myanmar minority group in the Western media. The Rohingyas as Muslims are set signifiers to them for whom there are fixed signified. The signified is that the Rohingyas, as Muslims, are terrorists and so, they must be the subjects of prey. As there is the possibility of their connectivity with the terrorists, national or international, they can easily be ignored. The internationally accepted humanitarian ideologies are not to be applied for these people as they are Muslims. The valuable airtime of the electronic media should not be spent for letting the world know about these people's real conditions. In addition, the use of the most desired and expensive column-space in the printing media is considered too much benevolence for representing such as group which is naturally taken as the root of global terrorism. The Rohingya women and children are to be spared just for their religiosity. The international definition of the term refugee is not to be applicable for these people as the scholars spend much time to posit these people in such an epistemological position which determines their identity not as refugees but as affected people. The conventional media, as parts of the social, cultural, political, ideological, and 
economic realities of the Western countries, are also motivated, affected, and to some extent, guided by the anglophile ideas. Because of this fixity of the signified, the canonical media are always reluctant to represent the Rohingyas in their timeline as it should be.

\section{NEW MEDIA: LITERATURE}

New media as a "plural noun treated as a singular subject" (Chun and Keenun, 01), emerged in the field of media in the beginning of the last two decades of the previous century. It came with revolutionary changes in the field of media as well as the perceptions of the commoners. It is not the televised media rather it refers to the computerization of the media. It refers to Facebook, Twitter, Whatsup etc. Chin, in his introductory note of the text entitled New Media, Old Media: A History and Theory Reader, refers to it as an entity having "singular plurality" (01). The authors of this article have taken this idea as one of the key issues in their arguments to establish the fact that representation in the conventional or televised media is determined by many existing parameters and so, they are limited and guided. On the other hand, new media is not guided by isms and ideologies of any social, cultural, or political groups. If Facebook is considered here, it becomes clear how reporting through statuses are independent and beyond any corporate policies. Chun emphasizes on this in his observation on new media where he says, "new media was not simply digital media: that is, it was not digitalized forms of other media ... but rather an interactive medium or form of distribution as independent as the information it relayed" (01). Apart from this independence of expression of the contributors in new media, it shows all deconstructive traits in their comments which include "endless play in language and literary texts, the unreliability of any meaning, the openness of texts, the instability of language, the unfinalizability of any meaning or text, the relationships between words, meanings and texts as intrinsic to meaning rather than the words themselves" (Nayar, 40). Thus, the new media has come out of the canonical media presentation of any race or idea and opens an endless arena of criticism, discussion, and analysis with more fluidity, non-fixity, and instability.

\section{Media and the Rohingyas}

CNN, in its official website available at https://edition.cnn.com/specials/asia/rohingya concentrates on the Rohingyas under the title "The Rohingya Crisis". In this news portal, they mostly report on the historical and political issues of the crisis ignoring the Rohingya's core issues which include the problem of the journey, the individual rape case, the children's issue, abortion, pregnancy, problem in interaction among the refugees and with the local Bangladeshis, religious issues, prostitution, maid's jobs etc. The inherent and very much incorporated problems that every individual and every family experiences in the new land are totally absent in the reports. Some titles used by the CNN reporters are cited here with a view to referring to the themes they have highlighted. They include: "Imprisonment, Torture, and Rape: Why Myanmar must be referred to the ICC", "UN calls for Genocide Tribunal over Rohingya Crisis", "broken Cell Phones could be the Key to Justice for the Rohingya", UN Granted Access to Rohingya Villages in Rakhain State", "Aung San Suu Kyi Admits Rohingya Crisis 'could have been handled better", "Will Myanmar's Genocide Generals Ever Face Justice" etc. These titles clearly establish the fact that the American mainstream newspaper does not take the social, cultural, religious, migrational, economic, feministic, ideological, cross -cultural issues into consideration through which the real picture of the Rohingya immigrants could be understood in more academic and epistemological manners.

$\mathrm{BBC}$, the giant British broadcasting agency, also follows the tradition of a corporate news agent in ignoring the peripheral aspects of the Rohingya immigrants. The analysis of the titles of their lead-news regarding the Rohingya ensures that the problem is not very impacting to their editorial policy though it is one of the greatest migrations the world has every experienced. The titles, as found at https://www.bbc.com/news/world-asia-38168917, include "Rohingya Villages 'Destroyed' in Myanmar ", "Myanmar 's Rohingya Muslims: Glimmer of Hope at Last", "Bangladesh Presses Myanmar as Rohingya Flee across Border”, etc.

The analysis of both of CNN and BBC reports leads us to the understanding of their attitudes that their reporting policies regarding the Rohingyas are guided by "elite political attitudes" (5), as observed by Berry and others in their report for the United Nations High Commission for Refugees entitled "Press Coverage of the Refugee and Migrant Crisis in the EU: A Content: A Content Analysis of Five European Countries" to refer to the European leaders' reluctance to take pragmatic initiatives to solve the refugee problems. The news giants are also very indeterminate regarding a far-distant problem and moreover, it is about the Muslims who are usually not accepted liberally by the European counterparts because of 9/11 occurrence.

Amanda Alencer, in her "Refugee Integration and Social Meida: A Local and Experiential Perspective", concentrates on the integration of the refugees in the new abode. To her, integration refers to a bunch in paradigms including "employment, education, linguistic competence, cultural belonging, social capital, rights, and citizenship" (2). This line of points can be lengthened by adding marital issues, orphanhistory, psychological trauma as inevitable phenomenon as the effect of migration. To the refugees, this framework is very important for substantially confirming their existence in the new land. Our argument is that all of these issues are not properly addressed in the conventional media both in the national and international levels. They always deal with the governmental activities to solve the bilateral problem. A deep analysis of the roles played by them establishes the fact that they ignore the everyday anxieties, experiences, and social, cultural, religious, gender-related, and above all, ideological 
interactions. Their roles are very structural in perception as they work within their corporate boundaries.

\section{New Media and the Rohingyas}

The refugee problem, throughout the whole world, is a discourse with multi-level narratives. It, as commented by Farzana, "always contains multiple, and often, conflicting, narratives from the perspectives of the authorities and those affected" (59). These multifarious narratives are widened with the emergence of the new media and it is applicable both for the oppressors and the oppressed. The representation of the Rohingyas in new media is wide, multifarious, and unending. The contributors from different fronts have contributed a lot about the army suppression on them which has created a lot of groups in different corners of the world to voice against this oppression. The deconstructive perception of the non-fixity, fluidity, and openness of meaning of the Facebook contributors about the subjugation of the Myanmar army on the Rohingya women and the children is not authentically reflected on the conventional media while it is highly contributed by the users of the tools offered by new media from different dimensions.

\section{CONCLUSION}

The Rohingyas, migrated to Bangladesh, are from all classes of people from Arakhan state who are politically, socially, culturally, religiously, economically, and ideologically subjugated by the hegemonic Myanmar Government. In the name of political cleansing, many of the people were brutally killed by the army and the rest of them were compelled to migrate to the nearby country Bangladesh. Throughout the whole world, the Rohingya migration stirred the whole world as it was the single largest community migrated from one country to another. This article shows that the canonical media has failed to bring out the integrated framework of the refugees to address all of their alma mater because of their political, economic, and cultural realities while new media, in which the mass people can participate without any corporate interests, the participants can easily record the everyday suffering of the common Rohingya refugees. For example, some Rohingya women are compelled to get involved in prostitution while some are sold to those religious agents as wives who marry them as parts of their holy responsibilities to the fellow Muslim women. But in reality, they are simply used as sex-partners. On the other hand, many young women are engaged as maids in different affluent Bangladeshi families in which, they not only work as maids, but also they are sexually harassed. In this article, we have examined these issues from qualitative perspective and come to the conclusion that the conventional media has failed to accommodate these aspects in their canonical transmission or publishing policies and thus, works structurally while these issues are widely recorded and discussed in different new media such as Facebook or Twitter and in this way, they are more discoursed.

\section{REFERENCE}

[1] Allan, Stuart. The Routledge Companion to News and Journalism. Routledge, 2009

[2] Alencar, Amanda, "Refugee Integration and Social Media: A Local and Experiential Perspective". Information, Communication, and Society. UK: Routledge Taylor and Francis Group, 2017. Available at http://dx.doi.org/10.1080/1369118X.2017.1340500. viewed on 22nd September, 2018

[3] Berry, Mike, Garcia-Blanco, Inaki, Moore, Kerry. "Press Coverage of the Refugee and Migrant Crisis in the EU: A Content Analysis of Five European Countries". Available at http://www.unhcr.org/56bb369c9.pdf, Dec 2015. Viewed on $21^{\text {st }}$ September, 2018.

[4] Bhatia, Monish, Poynting, Scott, Tofail, Waqas. (Edt.). Media, Crime, and Racism. Palgrave Macmillan, 2018. P. 169

[5] Chinenye, M., "Print Media Objectivity and Advertising Revenue". International Multidisciplinary Journal of Ethopia.

[6] Chun, Wendy Hui, Keenan, Thomas, (Edt.), New Media, Old Media: A History and Theory Reader. New York: Routledge, 2006. Web

[7] Cole, T. J., The Great Brexit Swindle: Why the Mega Rich and Free Market Fanatics Conspired to Force Britain from the European Union. W. Sussex: Clairview Books Ltd., 2016. Web

[8] Corfe, Robert, Freedom from America: For Safeguarding Democracy \& the Economic \& the Cultural Integrity of Peoples. Southgate Green: Arena Books, 2006. Web

[9] Croteau, David, Hoyness, William, The Business of Midia: Corporate Media and the Public Interest. New Delhi: Pine Forge Press, 2006. Web

[10] Farjana, Kazi Fahmida, Memories of Burmese Rohingya Refugees: Contested Identity and Belonging, New York: Palgrave Macmillan, 2017

[11] Fourie, Peter J., (Edt), Media Studies: Media Hitory, Meida and Society. Capetown: Juta \& Company Ltd., 2008. Web

[12] Green, Todd H., Presumed Guilty: Why We Should Not Ask Muslims to Condemn Terrorism. Minneapolis: Fortress Press, 2018

[13] McQuail, Denis. "Media Policy: Premature Obsequies?". Edt. Howard Tumber, Media Power, Professionals, and Policies. Routledge, 2000

[14] Nayar, Pramod K., Contemporary Literary and Cultural Theory: From Structuralism to Ecocriticism. New Delhi: Dorling Kindersley (India) Pvt. Ltd, 2010. Web

[15] Pinazza, Francisco, (Edt.), Populism and the Mirror of Democracy. London: Verso, 2005. Web

[16] Said, Edward, W., Orientalism. London: Penguine Books Ltd., 1978. Print

[17] "The Rohingya Crisis", available at https://edition.cnn.com/specials/asia/rohingya. Viewed on 21st September, 2018.

[18] "Who will Help Myanmar 's Rohingya?", available at https://www.bbc.com/news/world-asia-38168917. Viewed on 21st September, 2018. 